has to come from the combustion of coal. Many of the plastics are also derived from coal or petroleum, but being organic compounds, there is always the possibility of producing them from vegetable matter, as for example through the production of alcohol by fermentation and its conversion into more complex compounds. Such a procedure would be in line with the policy of depending on current revenue, derived from plants, rather than drawing unnecessarily on mineral capital, which once exhausted is not replaced.

Much might be said of means of economizing metals : the use of structures built up by welding, in place of heavy castings ; the combination of concrete with steel in buildings and bridges ; the saving of valuable metals by employing them as thin coatings on mild steel in chemical plant, and so on; but space does not permit. As new materials come into use and new techniques are developed, while at the same time the known reserves of some indispensable metals are being depleted, it becomes clear that the efficient use of the world's mineral resources demands systematic planning. First of all, a far more thorough world survey is needed, gathering together the information collected by prospectors in the interest of large industrial corporations as well as by the various national surveys. Such a survey would be the essential basis of any system of international control of mineral resources.

\section{GROWING-POINTS IN THE STUDY OF GROWTH AND DEVELOPMENT}

\author{
By Dr. JOSEPH NEEDHAM, F.R.S.
}

$\mathrm{E}$ XPERIMENTAL morphology is a subject which has long suffered from the scattered nature of its publication mechanisms. The great series of the Archiv. f. Entwicklungsmechanik was at one time central, but is now, alas! no longer available, and though the American anatomical journals long offered a home for such studies, much of the work appeared in the proceedings of learned societies not always very accessible (for example, the Finnish contributions). Work on the borderlines of biochemistry and morphology, in particular, was widely scattered. Hence the need for some periodical publications of the regular conference type, to do for experimental morphology what the Cold Spring Harbor Symposia had begun to do so well for general physiology. The symposia now under review* are often referred to by the name of "Growth Supplements" ; the correct description enshrining an auspicious pun. They will certainly stimulate the growth of our knowledge about growth and differentiation.

- First Symposium on Development and Growth, 1939; North Truro, Mass., ed. N. J. Berrill; contributions by W. H. Lewis, $P$. W Gregory, C. Stern, C. H. Waddington, J. Needham, O. Glaser, O. E. chotté, E. W. Sinott, J. H. Woodger; Supplement to Growth, vol. 3. Second Symposium on Development and Growth, 1940 ; Salisbury Cove, Maine; contributions by 0 . L. Sponsler, R. Schœnheimer, $H$. reundlich, G. S. Avery, D. M. Whitaker, A. B. Dawson, V. C. Twitty H. S. N. Greene, and F.'S. C. Northrop. Supplement to Growth, vol. 4 .' Third Symposium on Development and Growth, 1941 ; Hanover, New Hampshire; contributions by F. O. Schmitt, v. Tartar, K. B. Raper, A. F. Blakeslee, N. J. Berrill, A. H. Hersh, L. C. Dunn, and P. Weiss. Supplement to Growth, vol. 5 .

All the Growth Symposia are obtainable as follows: by members of the Society for the Study of Development and Growth on applica-
tion to Dr. J. W. Wilson, Biology Department, Brown University, tion to Dr. J. W. Wilson, Biology Department, Brown University, Providence, R.I., U.S.A.; by non-members on application to the Editors of Growth, Dairy Building, Cornell University, Ithaca, N.Y.
U.S.A. Prices : for members, vol. 1 , 1 dollar, vols. 2 and 3,2 dollars for non-members, vol. 1,2 dollars; vols. 2 and 3,3 dollars.
I had the good fortune to be present at the first two of these symposia. North Truro is a village lost among the sandy hills of Cape Cod, and there, in the spacious village schoolroom, under blue skies but with the shadow of war hanging over us, some hundred members met to discuss problems of experimental morphology. The proceedings were opened by an excellent account of the contributions of the explantation method by the veteran investigator, Warren N. Lewis. It is often forgotten that the discovery of the inductive action of the eye-cup on the presumptive lens tissue was discovered by him and Hans Spemann independently about the turn of the century, and that seven years later he narrowly missed finding that inductive action of the primary organizer itself which had to await the classical paper of Spemann and Hilde Mangold in 1924. Much of the rest of the North Truro symposium was, in fact, occupied by discussions of the present state of the organizer problem, in which valuable contributions were made by Paul Weiss. Arising out of Oscar Schotté's paper, considerable attention was given to the re-acquisition of competence by tissues undergoing regeneration, and the term 'recuperation' was proposed and adopted for this phenomenon. Curt Stern's paper was also very stimulating on the relation of genes and inductors. As regards growth proper, there was a good summary of the work on glutathione as a genetically controlled diffusible inductor working on body-size, by P. W. Gregory; and E. W. Sinott summarized his interesting investigations on the morphogenetic fields of the fruits of the Cucurbitaceæ.

The second symposium took place in the following summer at Salisbury Cove, Maine, and as there was not sufficient accommodation at the Marine Biological Station there for the meetings, we were kindly given the use of a charming wooden chapel in New England style, to which the members of the symposium were summoned by the ringing of the bell by the chairman. Here several brilliant summaries were given, particularly those by Douglas Whitaker on the mutual interactions of cells as exhibited in the early development of Fucus "eggs"; and by V. C. Twitty on the size-controlling factors in amphibian development, in which the complex questions of self-wise and neighbour-wise phenomena in growth of parts after transplantation and in physiological behaviour such as cardiac rhythm and pigment formation were lucidly described. $\mathbf{H}$. Greene's account of the pathology of development, genetically produced abnormalities, etc., will also be found of much interest. For the biochemist, there was a brilliant account by the great physical chemist Freundlich (then at Wisconsin) of the colloid chemistry of development and growth, paying special attention to liquid crystalline phases in living cells, birefringence, importance of anisometric protein particles, etc. This article has also the melancholy interest of being the last which Herbert Freundlich wrote before his death. There was also an animated discussion of protein structure by O. L. Sponsler, well known as one of the earliest workers to apply the methods of X-ray crystallography to living structures (plant cell-walls).

The third symposium opened with an exceptionally important article by F. O. Schmitt on "protein patterns" in cells. This centred around the question of what it is exactly which happens to the cells of the presumptive neural tube in the embryo when, under the influence of the primary inductor, they 
change their shape by a profound elongation. While some workers are inclined to lay greatest emphasis on the existence of sub-microscopic anisometric protein micelles in the cytoplasm; while others suggest that the main factors are located in an ectoplasm similar to that which we know is responsible for the cell-shape changes in echinoderm egg cell-divisions; Schmitt and his colleagues direct attention rather to the cell-surface itself. The evidence for the 'zip-fastener' theory of neurulation must be read in the original, but it is sure that the time has come for an intensive attack on the cell surfaces by colloid chemists familiar with the properties of interfacial protein and lipo-protein monolayers. The recent fundamental work of J. Holtfreter on 'tissue affinities' in morphogenesis looks in the same direction.

Doubtless the most remarkable article in the third symposium is that of K. B. Raper on the developmental patterns in the simple slime-moulds. The facts there reported appear nothing short of amazing to the specialist in better-known fields of morphological study. Slime-moulds had indeed been coming into the limelight through the curious experiments of A. R. Moore on the ability of their protoplasm to pass through very fine filters, but its destruction if forced through much coarser filter pores. But now Raper describes for the benefit of biologists accustomed to less startling material how myriads of myxamœbæ of wholly different spore origin and initially equal potentialities come together in enormous numbers, integrate themselves into a cooperative functioning whole, and afterwards differentiate along specific lines within prescribed limits to produce a single fructification. The article is well illustrated with photographs and drawings showing how the myxamœbæ stream together towards a central mass or peg, which then lifts itself up and differentiates into a highly complex and specifically characteristic sorocarp. Congregations of myxamobæ of different species move in to different centres. As if this behaviour were not enough, in some species the conjoined mass or "pseudoplasmodium" does a good deal of migration before it settles down and begins to differentiate. All these phenomena allow of much experimental analysis which has scarcely as yet been begun : the nature of the factors leading to aggregation, the mechanism of the movement of the pseudoplasmodia, and the factors governing differentiation of the sorocarp.

More familiar growth phenomena were not overlooked in the third symposium, however. A. F. Blakeslee gave a very interesting discussion of general growth patterns in plants, and heterogonic (allometric) growth problems in animals were well reviewed by A. H. Hersh. Finally, P. Weiss discussed the mechanics of nerve growth, dealing among other things with his 'deplantation' experiments, in which a piece of isolated nerve-cord and a detached limb are both implanted into the gelatinous connective tissue of the amphibian fin. Thus the gradual innervation of the limb and the spontaneous origination of rhythmical impulses from the nerve cord can be studied, as if in an elaborate form of tissue culture, subject only to the unavoidable endocrine environment of the host animal.

The above descriptions have not been able to do justice to more than a few of the admirable reviews in these symposia. By the time when this notice appears, the Fourth Symposium on Development and Growth, held at North Truro in August 1942, will be in course of publication. It was devoted to the general theme of the "Developmental Responses to Specific Chemical Agents" and included contributions by K. G. Stern on growth as a problem of chemical catalysis; E. L. Tatum on the relations between genes and growth hormones; E. J. Boell on the physiological and biochemical analysis of organizer action; P. R. White on developmental responses of isolated plant tissues; E. Allen on tissue growth and the sex hormones; F. C. McLean on ossification; O. A. Bessey on tissue responses to vitamin deficiencies; and A. J. Riker on pathological growth. It will certainly be as indispensable as the symposia which have preceded it.

If the present review serves to direct the attention of British experimental morphologists, in the widest sense of the term, to a series of conferences which are likely to remain for a long time the centre of these studies, and which, when the present troubles are over, may again unite biologists from both sides of the Atlantic, it will have achieved its purpose.

\section{TEACHING OF COLOUR IN SCHOOLS}

F DUCATIONAL reforms, large and small, are in the air. A great many people are taking advantage of the upheaval produced by the War to overhaul the existing educational machinery and to discover its weaknesses. Sometimes the material that is taught needs modernizing, sometimes it is the method of teaching that is wrong, sometimes there is a failure to arouse the latent interest and enthusiasm of a child in the fascinating natural phenomena that abound.

The subject of colour can occupy only a very small corner in the eurriculum of school or university, but the phenomena of colour are so intimately woven into the pattern of human experience that what is taught is worthy of the best possible presentation. It is not an easy subject since there are too many avenues of approach - the physicist will want to start from the spectrum, the physiologist from the retina, the psychologist from the sensation, the artist from the point of view of beauty and harmony-but at least it is to be hoped that one teacher will not be in conflict with another.

It was no doubt partly from high academic motives such as these that the Physical Society Colour Group interested itself in the teaching of colour, but the Group also has its own problems which in part arise from the very diverse instruction on colour which members of the Group have received in earlier days. Some of these problems are concerned with termino. logy, which is anything but uniform; some are concerned with more fundamental matters, in which the principles accepted almost as axioms by one group of workers are neither understood nor accepted by other groups. Nothing would be more welcome to technical workers in colour than that their subject should be taught in a generally approved and consistent manner from the nursery upwards.

Co-ordination and combined operations are familiar phrases in these days and they might well be applied to the meeting arranged by the Colour Group on September 11 at the Imperial College of Science and Technology. Mr. E. G. Savage, education officer of 